\title{
Critical path of women in situation of violence: an integrative literature review
}

\author{
Rota crítica de mulheres em situação de violência: revisão integrativa da literatura \\ Rota crítica de mujeres en situación de violencia: revisión integrativa de la literatura
}

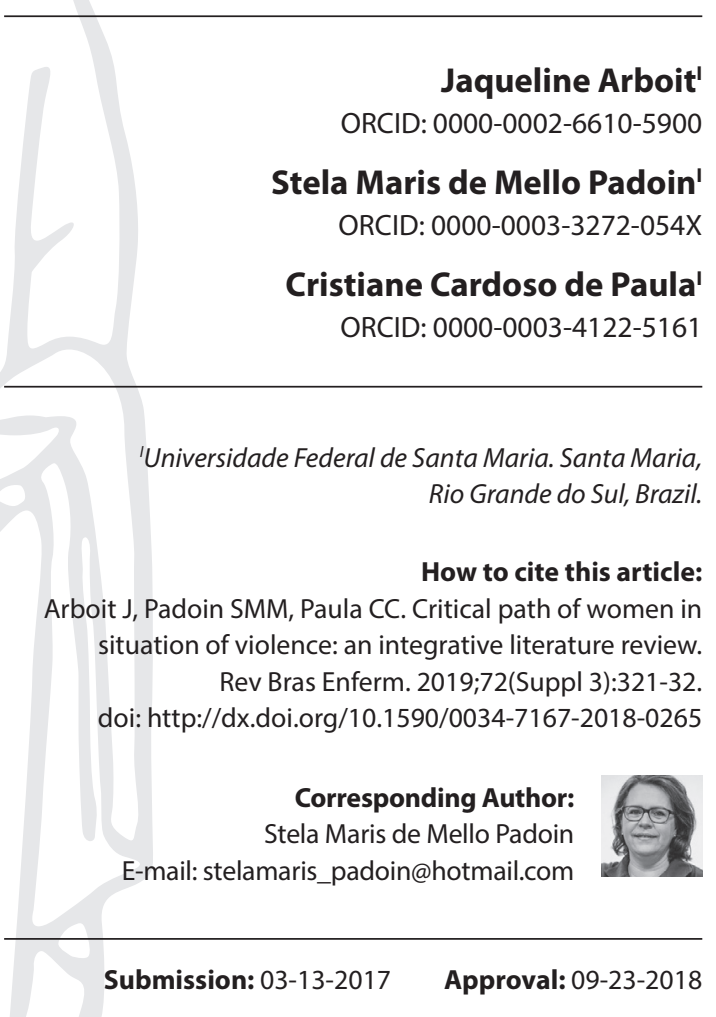

\begin{abstract}
Objective:To identify Brazilian and international scientific evidence on the critical path of women in situations of violence. Method: Integrative literature review developed in four databases and two electronic portals, in January 2017. Twenty-one full articles in English, Portuguese or Spanish from original researches were included in the time cut from 1994 to 2016, and which presented critical path elements, even without using this concept. Results: The critical path of women in situations of violence is constituted of elements related to their perceptions, actions and previous experiences regarding availability and quality of services, social representations of public servers and community and the results obtained in the search for help. Conclusion: Critical path elements are decisive for the women, and can promote, inhibit or delay the beginning of the route and consequently the end of situations of violence experienced by these women. Descriptors: Violence; Women's Health; Battered Women; Nursing; Review.
\end{abstract}

\section{RESUMO}

Objetivo: Identificar as evidências científicas nacionais e internacionais acerca da rota crítica de mulheres em situação de violência. Método: Revisão integrativa da literatura desenvolvida em quatro bases de dados e em dois portais eletrônicos, em janeiro de 2017. Foram incluídos 21 artigos oriundos de pesquisa original, na íntegra, em inglês, português ou espanhol, no recorte temporal de 1994 a 2016 e que apresentassem elementos da rota crítica, mesmo sem utilizar esse conceito. Resultados: Evidenciou-se que a rota crítica de mulheres em situação de violência é constituída de elementos relacionados tanto às percepções, ações e experiências prévias das mulheres, quanto à disponibilidade e qualidade dos serviços, representações sociais dos servidores e comunidade e os resultados obtidos na busca de ajuda. Conclusão: Os elementos da rota crítica são determinantes para as mulheres, podendo impulsionar, inibir ou retardar o início da rota e consequentemente o desfecho das situações de violência vivenciadas por essas.

Descritores: Violência; Saúde da Mulher; Mulheres Agredidas; Enfermagem; Revisão.

\section{RESUMEN}

Objetivo: Identificar las evidencias científicas nacionales e internacionales acerca de la ruta crítica de mujeres en situación de violencia. Método: Revisión integrativa de la literatura desarrollada en cuatro bases de datos y en dos portales electrónicos en enero de 2017. 21 se incluyeron los artículos provienen de una investigación original en su totalidad en inglés, portugués o español, en el marco de tiempo 1994-2016 y para proporcionar los elementos de la ruta crítica, incluso sin el uso de este concepto. Resultados: Se evidenció que la ruta crítica de mujeres en situación de violencia está constituida de elementos relacionados tanto a las percepciones, acciones y experiencias previas de las mujeres, en cuanto a la disponibilidad y calidad de los servicios, representaciones sociales de los servidores y comunidad y los resultados obtenidos en la búsqueda de ayudar. Conclusión: Los elementos de la ruta crítica son determinantes para las mujeres, pudiendo impulsar, inhibir o retardar el inicio de la ruta y consecuentemente el final de las situaciones de violencia vivenciadas por essas.

Descriptores: Violencia; Salud de la Mujer; Mujeres Maltratadas; Enfermería; Revisión. 


\section{INTRODUCTION}

Violence against women is considered a public health problem and a violation of human rights ${ }^{(1)}$, as well as one of the main obstacles to gender equality ${ }^{(2)}$. It is every act of violence perpetrated against a woman that results in physical, psychological and sexual suffering, as well as threats and deprivation of freedom ${ }^{(2)}$. Studies indicate that the main offenders of the women are people without consanguineous bonds, chosen for the intimate coexistence, namely: husbands, partners, boyfriends and ex-partners ${ }^{(3-4)}$.

This problem has undesirable consequences in the short and long term, also the ones related to the health of the women who experience it. Among these health-related consequences are sleep disorders, fatigue, nervousness, low self-esteem, isolation, lack of appetite and hematomas ${ }^{(5)}$. It is worth noting that a longitudinal study has shown that violence and abuse increase the probability of occurrence of depression in women with no previous history of symptoms ${ }^{(6)}$. Also, women who experienced intimate partner violence were twice as likely to present psychological distress, somatic complaints and to use psychotropic or analgesic medication when compared to women who did not experience violence ${ }^{(7)}$.

Despite these consequences, there are many reasons why women who experience violence remain in this situation. The fear of the constant threats from the husband and/or partner, the economic dependence on this partner and the concern with the children stand out $^{(8)}$. On the other hand, when women decide to break the cycle of violence, what Sagot ${ }^{(9)}$ calls the "critical path" begins. It comprises a set of actions carried out by women in situation of violence that begins after the women's decision to rupture the cycle of violence, through the search of support in the social networks and of services available, breaking the silence and making the situation public. The critical path is complex and non-linear, presenting elements related to the women's perceptions and their actions, and to social responses along the way, both in relation to the family and community context as well as to the institutional context ${ }^{(9)}$.

In view of the above and in line with the Sustainable Development Agenda, which recognizes that the elimination of violence against women is fundamental for sustainable human development and for the health of all $^{(10)}$, this review sought subsidies to develop strategies to qualify care for women in situations of violence.

\section{OBJECTIVE}

This study aims to identify Brazilian and international scientific evidence about the critical path of women in situations of violence.

\section{METHOD}

\section{Ethical aspects}

As it is a review study, without involving human beings, it does not require approval by the Research Ethics Committee.

\section{Study design}

This is an integrative review, which sought to aggregate and summarize research results on the specific topic, allowing the synthesis of multiple published studies. It is a relevant method for health and nursing, producing scientific evidence for the qualification of care practice ${ }^{(11)}$.

\section{Methodological framework and steps}

For the operationalization of this review, the steps below were followed $^{(11)}$ :

$1^{\text {st }}$ - Theme identification: critical path of women in situations of violence, and elaboration of the review question based on the PICo strategy ${ }^{(12)}$ - women (P - Population); critical path (I - Phenomenon of Interest); situation of violence (Co - Context): what is the Brazilian and international scientific evidence about the critical path of women in situations of violence?;

$2^{\text {nd }}$ - Establishment of inclusion criteria: to be a full article coming from an original research in English, Portuguese or Spanish; from 1994 to 2016 and that presented critical path elements, even without the use of this concept. The temporal cut is underpinned by the Inter-American Convention on the Prevention, Punishment, and Eradication of Violence against Women, which represents a milestone for the visibility of violence against women;

$3^{\text {rd }}$ - Definition of the information to be extracted from the articles/categorization: title, purpose of the study; year of publication; origin; study design (methodological approach and participants); and critical path elements. The information extracted were inserted into a chart;

$4^{\text {th }}$ - Evaluation of the studies included in the review: critical appraisal of the selected studies. The articles were classified hierarchically as to the level of evidence, according to the clinical question of the primary study ${ }^{(13)}$. For this assessment, a meeting was held in the research group with the presence of postgraduate students at master's and doctoral level. In cases where there was no consensus, a discussion was held with the leaders of the research group;

$5^{\text {th }}$ - Interpretation of results;

$6^{\text {th }}-$ Presentation of review/knowledge synthesis;

The selected databases were Web of Science, Cumulative Index of Nursing and Allied Health (CINAHL), National Library of Medicine (MEDLINE) via PubMed portal and Scopus. The survey of studies was also carried out on electronic portals: Regional Portal of the Virtual Health Library (VHL) and Portal of Periodicals of the Coordination for the Improvement of Higher Education Personnel (CAPES - Coordenação de Aperfeiçoamento de Pessoal de Nível Superior). This survey was carried out in January 2017.

To choose the Medical Subject Headings (MeSH) and Descriptors in Health Sciences (DECs), in order to expand the possibilities of retrieval of articles in the databases, the most used words were mapped in titles, abstracts and descriptors/key articles on the critical path of women in situations of violence. The following descriptors were used: Violence, Atrocities, Assaultive behavior, Behavior assaultive, Violência, Violência contra a mulher, Violência de gênero and Violência doméstica (in Portuguese). The words used to search the title and abstract were: Critical path, Critical paths, Critical path method, Rota crítica, Rotas críticas, Caminho crítico, Método do caminho crítico and Mulher (in Portuguese). The definition of critical path in MeSH and DeCS is centered on the conduct of health professionals. Sagot's 
critical path concept ${ }^{(9)}$ presents aspects related to the professionals' behavior, presenting factors related to the availability and quality of the services provided to women in situations of violence, as well as the representations of these professionals in relation to the violence experienced by these women.

The search of different databases and electronic portals, as well as the use of distinct search strategies both aimed at increasing the possibility of gathering evidence that answered the review question. In this process, the assistance of a librarian stands out. The databases and electronic portals and their search strategies are presented in Chart 1.

Chart 1 - Databases, electronic portals and search strategies employed in the integrative review about the critical path of women in situations of violence, 2017

\begin{tabular}{|l|l|}
\hline \multicolumn{1}{|c|}{$\begin{array}{c}\text { Database and } \\
\text { Electronic Portals }\end{array}$} & \multicolumn{1}{|c|}{ Search strategies } \\
\hline Web of Science & $\begin{array}{l}\text { "Critical path"OR "Critical path" OR"Critical } \\
\text { path method"AND"Violence"OR"Atrocities"OR } \\
\text { "Assaultive behavior"OR"Behavior assaultive" }\end{array}$ \\
\hline CINAHL & $\begin{array}{l}\text { "Critical path"OR "Critical paths"OR"Critical path } \\
\text { method"AND"Violence" }\end{array}$ \\
\hline MEDLINE & $\begin{array}{l}\text { "Critical path method"OR"Critical path"AND } \\
\text { "Violence" }\end{array}$ \\
\hline Scopus & $\begin{array}{l}\text { "Critical path"OR"Critical path method"AND } \\
\text { "Violence" }\end{array}$ \\
\hline CAPES' Journals Portal & $\begin{array}{l}\text { "Rota crítica" OR "Rotas críticas"OR"Caminho } \\
\text { crítico"OR "Critical path method"OR"Critical } \\
\text { path"AND"Violência"OR"Mulher" }\end{array}$ \\
\hline VHL Regional Portal & $\begin{array}{l}\text { "Rota crítica"OR"Rotas críticas"OR"Método do } \\
\text { caminho crítico"AND"Violência contra a mulher" } \\
\text { OR"Violência de gênero"OR"Violência doméstica" }\end{array}$ \\
\hline
\end{tabular}

Another strategy used was the manual search in the references of articles included in the corpus, which were accessed via Scielo ${ }^{(12)}$.

In order to minimize the possible bias of the studies (error of selection and interpretation of the results), two researchers from the same research group carried out the search of the studies, the careful reading of the selected articles, of information extraction and critical appraisal of articles independently. At the end of this process, the extraction frames were compared. In the absence of consensus, a third reviewer was also contacted, who is also a member of the research group.

\section{RESULTS}

In the searches in databases and electronic portals, 63 productions were initially found. It should be noted that duplicate studies were accounted for only once. After the duplications were removed, 48 productions remained. Of these, 23 were excluded because they were not original articles, 11 because they did not present critical path elements and two because they were not found in full. Moreover, 12 articles were selected for full reading and eligibility evaluation. Of these articles, 10 answered the question of revision and composed the corpus of the study. Afterwards, the manual search was carried out in the list of references of the articles included in the study, incorporating 11 articles. Thus, the corpus of the study was composed of 21 articles. The flowchart (Figure 1) describes the path for the selection of articles, based on the Prisma model[14).

Regarding the characterization of the articles, 13 (62.0\%) were published in the period from 2011 to 2015 according to the year of publication. The methodological approach was predominantly qualitative in 14 articles (66.6\%). As far as origin is concerned, 18 $(85.7 \%)$ articles were developed in Europe. With regard to the participants, 9 (42.8\%) articles were developed with women. As to the classification of the evidence of the articles, according to the type of clinical question ${ }^{(12)}, 17$ (80.9\%) were directed to the meaning, being 14 with a level of 2 . Chart 2 shows the characteristics of the articles regarding title, objective, year/country, outlining and level of evidence/clinical question.

The synthesis of the evidences found in the articles was carried out according to the Critical Path diagram proposed by Sagot $^{(9)}$ (Figure 2).

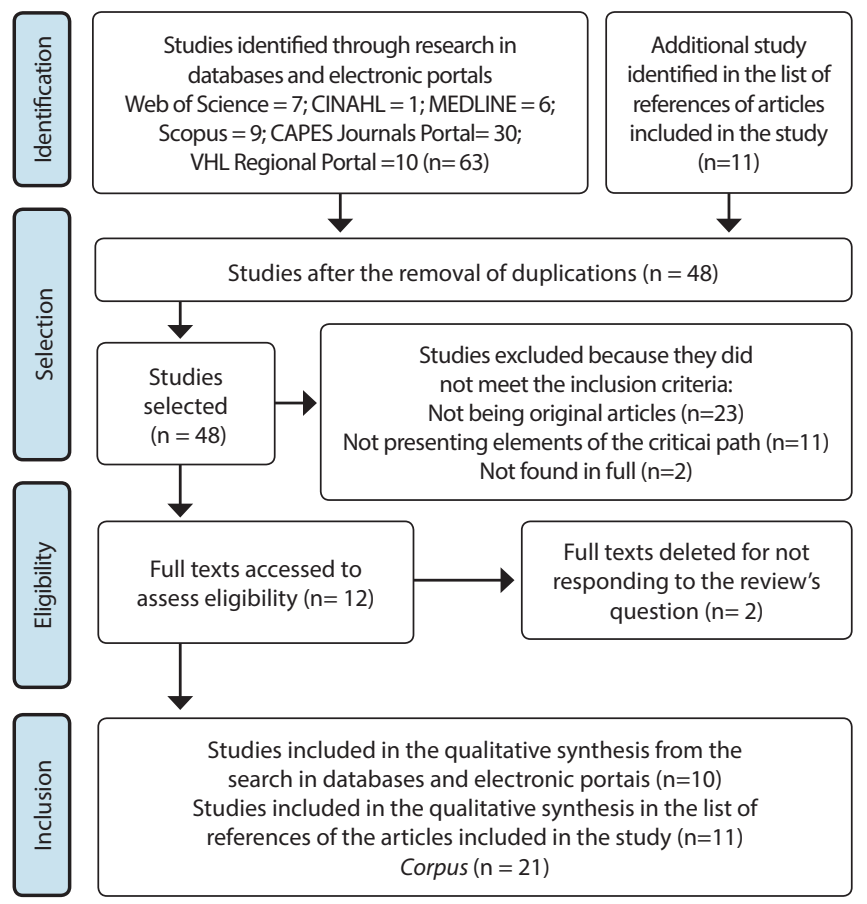

Source: Moher et. al ${ }^{(14)}$ adapted.

Figure 1 - Flowchart of selection articles for the integrative review about the critical path of women in situations of violence, based on the PRISMA model ${ }^{(14)}, 2017$

Chart 2 - Characteristics of the articles regarding title, objective, year/country, outlining and level of evidence/clinical question, 2017

\begin{tabular}{|l|l|c|l|l|}
\hline Title & Objective & Year/Country & Outlining & $\begin{array}{l}\text { Level of evidence/ } \\
\text { Clinical question }\end{array}$ \\
\hline $\begin{array}{l}\text { Repercussions of the Maria da } \\
\begin{array}{l}\text { Penha law in tackling gender } \\
\text { violence }\end{array}\end{array}$ & $\begin{array}{l}\text { To present what the research participants think about } \\
\text { the Maria da Penha Law. }\end{array}$ & $\begin{array}{l}2013 \\
\text { Brazil }\end{array}$ & $\begin{array}{l}\text { Qualitative } \\
\mathrm{n}=21 \text { women and } \\
25 \text { professionals }\end{array}$ & $\begin{array}{l}\mathrm{L} 2 \\
\text { (Meaning/ } \\
\text { Experience) }\end{array}$ \\
\hline
\end{tabular}


Chart 2

\begin{tabular}{|c|c|c|c|c|}
\hline Title & Objective & Year/Country & Outlining & $\begin{array}{l}\text { Level of evidence/ } \\
\text { Clinical question }\end{array}$ \\
\hline $\begin{array}{l}\text { Critical trajectories of female victims } \\
\text { of gender violence: discourse } \\
\text { analysis of women and staff } \\
\text { professionals in Porto Alegre, Rio } \\
\text { Grande do Sul State, Brazil }{ }^{(16)}\end{array}$ & $\begin{array}{l}\text { To establish the trajectory of women in situation } \\
\text { of gender violence, identifying the critical points, } \\
\text { proposing intervention measures and fomenting the } \\
\text { construction of networks to combat violence in the city } \\
\text { of Porto Alegre. }\end{array}$ & $\begin{array}{l}2011 \\
\text { Brazil }\end{array}$ & $\begin{array}{l}\text { Qualitative } \\
\mathrm{n}=21 \text { women and } \\
25 \text { professionals }\end{array}$ & $\begin{array}{l}\text { L2 } \\
\text { (Meaning/ } \\
\text { Experience) }\end{array}$ \\
\hline $\begin{array}{l}\text { The configuration of the social } \\
\text { network of women living in } \\
\text { domestic violence situations }{ }^{(17)}\end{array}$ & $\begin{array}{l}\text { To present the configuration of the social networks of } \\
\text { a group of women in a situation of domestic violence, } \\
\text { analyzed from a conception of social networks } \\
\text { that characterizes the nature of the bonds and the } \\
\text { exchanges that take place between the actors, and } \\
\text { investigates the material or symbolic objects that there } \\
\text { circulate. }\end{array}$ & $\begin{array}{l}2013 \\
\text { Brazil }\end{array}$ & $\begin{array}{l}\text { Qualitative } \\
\mathrm{n}=9 \text { women and } \\
8 \text { professionals }\end{array}$ & $\begin{array}{l}\text { L2 } \\
\text { (Meaning/ } \\
\text { Experience) }\end{array}$ \\
\hline $\begin{array}{l}\text { The Critical Path of women affected } \\
\text { by family violence in Latin America. } \\
\text { Violence Against Women Sagot }{ }^{(18)}\end{array}$ & $\begin{array}{l}\text { To analyze the actions carried out by women who } \\
\text { suffer violence, the answers found in their search for } \\
\text { obstacles and the availability and quality of services; } \\
\text { to gather and analyze the social meanings of family } \\
\text { violence that prevails among providers of health } \\
\text { services, law enforcement and judicial, education, and } \\
\text { nongovernmental sectors and communities in } 10 \text { Latin } \\
\text { American countries. }\end{array}$ & $\begin{array}{c}2005 \\
\text { Belize, } \\
\text { Guatemala, } \\
\text { El Salvador, } \\
\text { Honduras, } \\
\text { Nicaragua, } \\
\text { Costa Rica, } \\
\text { Panama, Peru, } \\
\text { Bolivia and } \\
\text { Ecuador }\end{array}$ & $\begin{array}{l}\text { Qualitative } \\
\mathrm{n}=900 \text { (women, } \\
\text { professionals and } \\
\text { community) }\end{array}$ & $\begin{array}{l}\text { L2 } \\
\text { (Meaning/ } \\
\text { Experience) }\end{array}$ \\
\hline $\begin{array}{l}\text { Women facing violence: the voice } \\
\text { of social workers }^{(19)}\end{array}$ & $\begin{array}{l}\text { To know the actions and trajectories of women in } \\
\text { search of alternatives for overcoming the situation of } \\
\text { violence in the city of São Leopoldo, by analyzing the } \\
\text { discursive practices of the Institution operators working } \\
\text { with gender violence in the municipality. }\end{array}$ & $\begin{array}{l}2008 \\
\text { Brazil }\end{array}$ & $\begin{array}{l}\text { Qualitative } \\
\mathrm{n}=12 \\
\text { professionals }\end{array}$ & $\begin{array}{l}\text { L2 } \\
\text { (Meaning/ } \\
\text { Experience) }\end{array}$ \\
\hline $\begin{array}{l}\text { Women's strategic responses to } \\
\text { violence in } \\
\text { Nicaragua }^{(20)}\end{array}$ & $\begin{array}{l}\text { To describe the responses of women in the city } \\
\text { of León, Nicaragua to partner abuse, and identify } \\
\text { contextual factors associated with the use of certain } \\
\text { coping mechanisms and the likelihood of permanent } \\
\text { separation. }\end{array}$ & $\begin{array}{l}2001 \\
\text { Nicaragua }\end{array}$ & $\begin{array}{l}\text { Quantitative } \\
\mathrm{n}=188 \text { women }\end{array}$ & $\begin{array}{l}\text { L4 } \\
\text { (Prognostic/ } \\
\text { Etiology) }\end{array}$ \\
\hline $\begin{array}{l}\text { Help-Seeking behaviors and } \\
\text { reasons for help seeking reported } \\
\text { by a representative sample of } \\
\text { women victims of intimate partner } \\
\text { violence in New Zealand }{ }^{(21)}\end{array}$ & $\begin{array}{l}\text { To report on the seeking behavior of women who have } \\
\text { experienced during their lives physical violence and / or } \\
\text { sexual violence by an intimate partner. }\end{array}$ & $\begin{array}{l}2010 \\
\text { New Zeland }\end{array}$ & $\begin{array}{l}\text { Quantitative } \\
\mathrm{n}=956 \text { women }\end{array}$ & $\begin{array}{l}\text { L4 } \\
\text { (Meaning/ } \\
\text { Experience) }\end{array}$ \\
\hline $\begin{array}{l}\text { Strategies and Help-Seeking } \\
\text { behavior among Mexican women } \\
\text { experiencing partner violence }{ }^{(22)}\end{array}$ & $\begin{array}{l}\text { To examine whether women who experienced } \\
\text { violence sought out law enforcement agencies, and } \\
\text { the characteristics of these women; to examine the } \\
\text { type of service and treatment they reported having } \\
\text { received from these agencies; to examine the reasons } \\
\text { why women do not seek help from police and law } \\
\text { enforcement agencies. }\end{array}$ & $\begin{array}{c}2013 \\
\text { Mexico }\end{array}$ & $\begin{array}{l}\text { Quanti-qualitative } \\
\mathrm{n}=89 \\
\text { professionals and } \\
22,639 \text { women }\end{array}$ & $\begin{array}{l}\mathrm{L} 2 \\
\text { (Meaning/ } \\
\text { Experience) }\end{array}$ \\
\hline $\begin{array}{l}\text { Facing violence by intimate partner: } \\
\text { the experience of women in an } \\
\text { urban area of Northeastern Brazil(23) }\end{array}$ & $\begin{array}{l}\text { To describe the forms of coping with intimate partner } \\
\text { violence adopted by women. }\end{array}$ & $\begin{array}{l}2012 \\
\text { Brazil }\end{array}$ & $\begin{array}{l}\text { Quantitative } \\
\mathrm{n}=283 \text { women }\end{array}$ & $\begin{array}{l}\text { L4 } \\
\text { (Meaning/ } \\
\text { Experience) }\end{array}$ \\
\hline $\begin{array}{l}\text { Domestically abused Brazilian } \\
\text { women's perceptions about } \\
\text { support and received support in its } \\
\text { social context }{ }^{(24)}\end{array}$ & $\begin{array}{l}\text { To identify the perception of women in situations of } \\
\text { violence regarding support and support received } \\
\text { in their social context, particularly institutionalized } \\
\text { resources to combat violence against women. }\end{array}$ & $\begin{array}{l}2010 \\
\text { Brazil }\end{array}$ & $\begin{array}{l}\text { Qualitative } \\
\mathrm{n}=57 \text { women }\end{array}$ & $\begin{array}{l}\text { L2 } \\
\text { (Meaning/ } \\
\text { Experience) }\end{array}$ \\
\hline $\begin{array}{l}\text { Factors associated with the } \\
\text { cessation of intimate partner } \\
\text { violence in women attending } \\
\text { Primary Care in Spain }\end{array}$ & $\begin{array}{l}\text { To detect differences in demographic characteristics } \\
\text { and personal resources, types of intimate partner } \\
\text { violence, age of onset and duration, and responses to } \\
\text { intimate partner violence among women in whom } \\
\text { violence persisted and in those in which it ceased; and } \\
\text { to identify factors that may be associated with a greater } \\
\text { likelihood of ending violent relationships. }\end{array}$ & $\begin{array}{l}2015 \\
\text { Spain }\end{array}$ & $\begin{array}{l}\text { Quantitative } \\
\mathrm{n}=2464 \text { women }\end{array}$ & $\begin{array}{l}\text { L4 } \\
\text { (Prognostic/ } \\
\text { Etiology)) }\end{array}$ \\
\hline $\begin{array}{l}\text { Silenced voices and structured } \\
\text { survival: battered women's help- } \\
\text { seeking }^{(26)}\end{array}$ & $\begin{array}{l}\text { To examine the various aspects of the search for help, } \\
\text { and the social and institutional responses to such } \\
\text { efforts from the perspective of survivors living in a } \\
\text { domestic violence shelter. }\end{array}$ & $\begin{array}{c}2007 \\
\text { United States }\end{array}$ & $\begin{array}{l}\text { Qualitative } \\
\mathrm{n}=19 \text { women }\end{array}$ & $\begin{array}{l}\text { L2 } \\
\text { (Meaning/ } \\
\text { Experience) }\end{array}$ \\
\hline
\end{tabular}




\begin{tabular}{|c|c|c|c|c|}
\hline Title & Objective & Year/Country & Outlining & $\begin{array}{l}\text { Level of evidence/ } \\
\text { Clinical question }\end{array}$ \\
\hline $\begin{array}{l}\text { Barriers to domestic violence } \\
\text { help-seeking: implications for } \\
\text { intervention }^{(27)}\end{array}$ & $\begin{array}{l}\text { To examine the reasons for abused women not to use } \\
\text { police, medical care and counseling assistance, as well } \\
\text { as informal help, defined as talking to a family member, } \\
\text { neighbor, acquaintance or friend. }\end{array}$ & $\begin{array}{l}2005 \\
\text { United States }\end{array}$ & $\begin{array}{l}\text { Quantitative } \\
\mathrm{n}=491 \text { women }\end{array}$ & $\begin{array}{l}\text { L4 } \\
\text { (Meaning/ } \\
\text { Experience) }\end{array}$ \\
\hline $\begin{array}{l}\text { Variations in women's help-seeking } \\
\text { in response to intimate partner } \\
\text { violence: findings from a Canadian } \\
\text { population-based study }{ }^{(28)}\end{array}$ & $\begin{array}{l}\text { To investigate the impact of sociodemographic } \\
\text { characteristics and characteristics of violence in seeking } \\
\text { formal and informal support from women in response } \\
\text { to intimate partner violence in a national survey of } \\
\text { Canadian families. }\end{array}$ & $\begin{array}{c}2011 \\
\text { Canada }\end{array}$ & $\begin{array}{l}\text { Quantitative } \\
\mathrm{n}=922 \text { women }\end{array}$ & $\begin{array}{l}\text { L4 } \\
\text { (Prognostic/ } \\
\text { Etiology) }\end{array}$ \\
\hline $\begin{array}{l}\text { Social resources to support women } \\
\text { living in situation of violence in } \\
\text { Ribeirão Preto, SP, in the perspective } \\
\text { of key informants }\end{array}$ & $\begin{array}{l}\text { To know the organizations involved in the care of } \\
\text { women in situation of violence, considering the } \\
\text { network of agencies and social equipment available } \\
\text { in a city of São Paulo. The investigation proposed to } \\
\text { understand the insertion of the different sectors, except } \\
\text { health, in this service network. }\end{array}$ & $\begin{array}{l}2011 \\
\text { Brazil }\end{array}$ & $\begin{array}{l}\text { Qualitative } \\
\mathrm{n}=11 \\
\text { professionals }\end{array}$ & $\begin{array}{l}\mathrm{L} 2 \\
\text { (Meaning/ } \\
\text { Experience) }\end{array}$ \\
\hline $\begin{array}{l}\text { Feminicide: narratives of gender } \\
\text { crimes }^{(30)}\end{array}$ & $\begin{array}{l}\text { To narrate stories of women murdered as a result of } \\
\text { gender inequalities, obtained through police inquiries } \\
\text { from the Homicide Office of the city of Porto Alegre, Rio } \\
\text { Grande do Sul State. }\end{array}$ & $\begin{array}{l}2013 \\
\text { Brazil }\end{array}$ & $\begin{array}{l}\text { Qualitative } \\
\mathrm{n}=6 \text { casos }\end{array}$ & $\begin{array}{l}\mathrm{L} 2 \\
\text { (Meaning/ } \\
\text { Experience) }\end{array}$ \\
\hline $\begin{array}{l}\text { Women in situations of violence: } \\
\text { limits of assistance }{ }^{(31)}\end{array}$ & $\begin{array}{l}\text { To analyze the limits of the practice of assistance to } \\
\text { women in situations of violence, from family health } \\
\text { teams in the care network. }\end{array}$ & $\begin{array}{l}2015 \\
\text { Brazil }\end{array}$ & $\begin{array}{l}\text { Qualitative } \\
\mathrm{n}=41 \\
\text { professionals }\end{array}$ & $\begin{array}{l}\text { L2 } \\
\text { (Meaning/ } \\
\text { Experience) }\end{array}$ \\
\hline $\begin{array}{l}\text { Ambiguity and contradictions in } \\
\text { the assistance provided for women } \\
\text { who suffer violence }^{(32)}\end{array}$ & $\begin{array}{l}\text { To identify the institutional dynamics that frame the } \\
\text { violated professional-woman relationship. }\end{array}$ & $\begin{array}{l}2011 \\
\text { Brazil }\end{array}$ & $\begin{array}{l}\text { Qualitative } \\
\mathrm{n}=21 \\
\text { professionals }\end{array}$ & $\begin{array}{l}\mathrm{L} 2 \\
\text { (Meaning/ } \\
\text { Experience) }\end{array}$ \\
\hline $\begin{array}{l}\text { Possibilities of a cross-sector } \\
\text { assistance network for women } \\
\text { subjected to violence }^{(33)}\end{array}$ & $\begin{array}{l}\text { To understand how the various services and their actors } \\
\text { perceive their place in the whole of assistance, relate } \\
\text { and integrate themselves, in their definition of the } \\
\text { problem and proposals for intervention. }\end{array}$ & $\begin{array}{l}2007 \\
\text { Brazil }\end{array}$ & $\begin{array}{l}\text { Qualitative } \\
\mathrm{n}=29 \\
\text { professionals }\end{array}$ & $\begin{array}{l}\text { L2 } \\
\text { (Meaning/ } \\
\text { Experience) }\end{array}$ \\
\hline $\begin{array}{l}\text { The response to gender violence } \\
\text { among Brazilian healthcare } \\
\text { professionals }^{(34)}\end{array}$ & $\begin{array}{l}\text { To identify the experience, behavior and feelings of } \\
\text { health professionals when addressing the needs of } \\
\text { women who experience intimate partner violence. }\end{array}$ & $\begin{array}{l}2013 \\
\text { Brazil }\end{array}$ & $\begin{array}{l}\text { Qualitative } \\
\mathrm{n}=24 \\
\text { professionals }\end{array}$ & $\begin{array}{l}\text { L2 } \\
\text { (Meaning/ } \\
\text { Experience) }\end{array}$ \\
\hline $\begin{array}{l}\text { Strategic responses to intimate } \\
\text { partner violence against women in } \\
\text { Spain: a national study in Primary } \\
\text { Care }^{(35)}\end{array}$ & $\begin{array}{l}\text { To describe women's response strategies to intimate } \\
\text { partner violence, to analyze the association between } \\
\text { women's personal resources, characteristics of intimate } \\
\text { partner violence (type, duration, and age of onset) and } \\
\text { response strategies adopted by women. }\end{array}$ & $\begin{array}{l}2012 \\
\text { Spain }\end{array}$ & $\begin{array}{l}\text { Quantitative } \\
\mathrm{n}=1469 \text { women }\end{array}$ & $\begin{array}{l}\text { L4 } \\
\text { (Prognostic/ } \\
\text { Etiology) }\end{array}$ \\
\hline
\end{tabular}

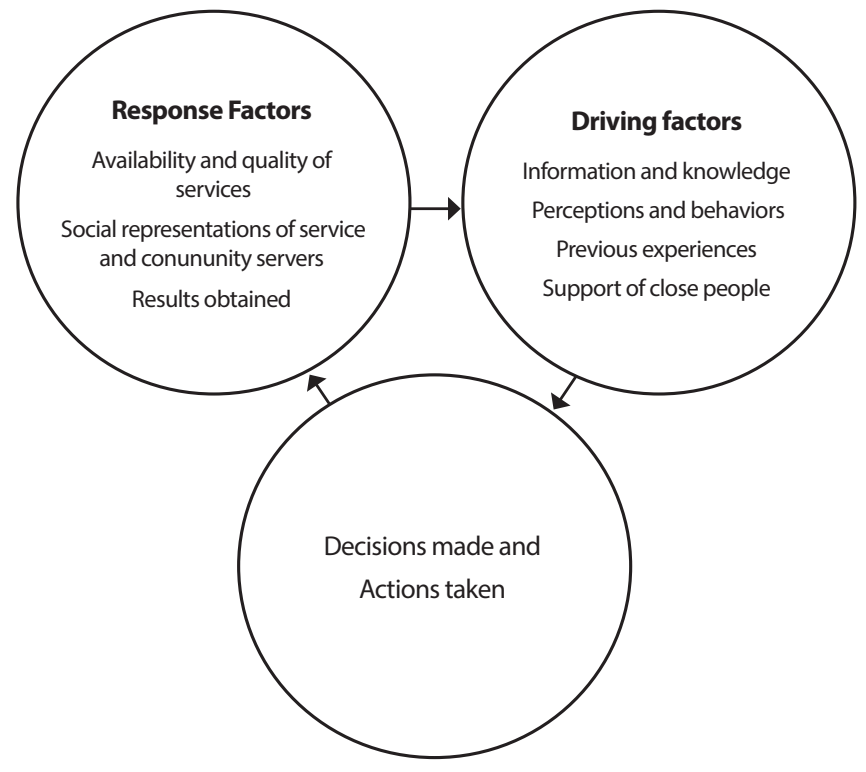

Figure 2 - Critical Path diagram proposed by Sagot ${ }^{(9)}$
In Chart 3, the synthesis of this review is presented according to the Critical Path diagram elements.

\section{DISCUSSION}

After the analysis and synthesis, it was decided to present the discussion according to the critical path elements presented in the results: driving factors; response factors; decisions made and actions taken.

\section{Driving factors}

The scientific evidence of the driving factors of the critical path of women in situations of violence, related to their information and knowledge, pointed to the search for information about legal devices, such as the Maria da Penha Law, regarding the Brazilian context. Such information is sought through various resources, whether on television, on the internet or in women's police stations ${ }^{(15)}$. They also indicated the prior knowledge of the existence of women's police 
Chart 3 - Synthesis of the evidence found in the articles of the integrative review about the critical path of women in situations of violence, 2017

\begin{tabular}{|c|c|c|c|}
\hline & \multirow{4}{*}{ 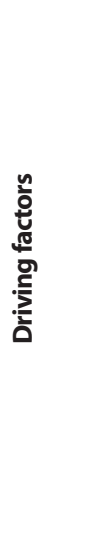 } & \multicolumn{2}{|l|}{$\begin{array}{l}\text { Information and knowledge } \\
\text { - Searching for information about legal devices } \\
\text { - Knowledge about the Women's Police Station }^{(16)}\end{array}$} \\
\hline & & \multicolumn{2}{|c|}{$\begin{array}{l}\text { Perceptions and behaviors } \\
\text { - To assume that to record the police report will solve the situation of violence } \mathrm{e}^{(16)} \\
\text { - To understand that you are experiencing a situation of violence } \mathrm{e}^{(16-17)} \\
\text { - To understand the public dimension of violence } \mathrm{e}^{(18)}\end{array}$} \\
\hline & & \multicolumn{2}{|l|}{$\begin{array}{l}\text { Previous experiences } \\
\text { - Having children } \\
\text { - Severe violence, fear or threats } \\
\text { (20-21,23-24) }\end{array}$} \\
\hline & & \multicolumn{2}{|l|}{$\begin{array}{l}\text { Support of close people } \\
\text { - Family and friends } s^{(16-17,21-28)}\end{array}$} \\
\hline \multirow{3}{*}{ 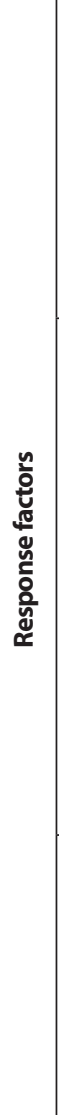 } & 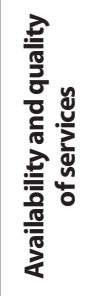 & $\begin{array}{l}\text { Negative } \\
\text { - Lack of protection and safety/legal measures difficult to } \\
\text { enforce } \\
\text { - Precariousness of physical structure, human resources of } \\
\text { institutions and social facilities }{ }^{(15-19,22,26,29,31-34)} \\
\text { - Absence of attendance protocols, specific forms for case } \\
\text { records and notification, referral and evaluation of the measures } \\
\text { adopted }{ }^{(15,16-19,24,26,31-34)} \\
\text { - Restructuring of the network } \\
\text { (15-19,24,26,29,31-33) }\end{array}$ & $\begin{array}{l}\text { Positive } \\
\text { - To escort the woman in the removal of her belongings } s^{(15-16)} \\
\text { - Partner removal from the house by the police authority } \\
\text { - Support of self-help groups }{ }^{(16,29,32)} \\
\text { - Referral of women to other services and institutions }{ }^{(16,18,29,32-33)} \\
\text { - Strengthening the women's self-esteem, economic independence, } \\
\text { empowerment, planning and reorganization of life } \\
\text { - Service provided by service professionals } s^{(16-19,29,29,22-33)}\end{array}$ \\
\hline & 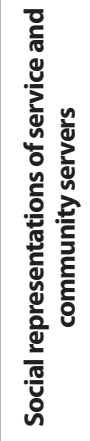 & $\begin{array}{l}\text { Negative } \\
\text { - Blame, discrimination against women, patriarchal conceptions } \\
\text { and moral judgment }{ }^{(15,17-19,24,26,31-33)} \\
\text { - Understanding violence as an illness to be treated }{ }^{(15)} \\
\text { - Consideration of law as unconstitutional }{ }^{(15)} \\
\text { - Understanding of the restraining order as a symbolic value role }{ }^{(15)} \\
\text { - Perception that violence poses no real danger }{ }^{(18)} \\
\text { - Understanding that other services are competing } \\
\text { - Depreciation of women's police station } \\
\text { - Knowledge only of your sector of activity } \\
\text { - Conceptions that violence against women is a matter of private } \\
\text { sphere }\end{array}$ & $\begin{array}{l}\text { Positive } \\
\text { - Understanding the law as an innovative legal device }{ }^{(15,29)} \\
\text { - Understanding the importance of networking } \\
\text { - Awareness of violence }{ }^{(29,32,34)}\end{array}$ \\
\hline & 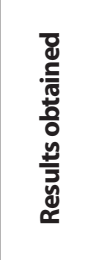 & $\begin{array}{l}\text { Negative } \\
\text { - Negative responses from the law enforcement, police and judicial } \\
\text { sectors } \\
\text { - Response of the health sector limited to the treatment of } \\
\text { injuries }^{(18,26,32)} \\
\text { - Absence of responses from the education sector }{ }^{(18)} \\
\text { - No one helped }\end{array}$ & $\begin{array}{l}\text { Positive } \\
\text { - Decreased cases of physical injury after the creation of the law }{ }^{(15)} \\
\text { - Cessation of intimate partner violence after registration of police report } \\
\text { or imprisonment }{ }^{(16,26)} \\
\text { - Support for women's organizations dedicated to violence against } \\
\text { women }^{(18)} \\
\text { - Positive responses from religious institutions }{ }^{(17-18)} \\
\text { - Good quality service from the police }{ }^{(21-22)}\end{array}$ \\
\hline 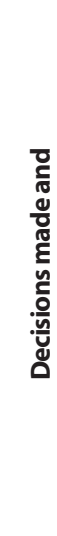 & & \multicolumn{2}{|c|}{ 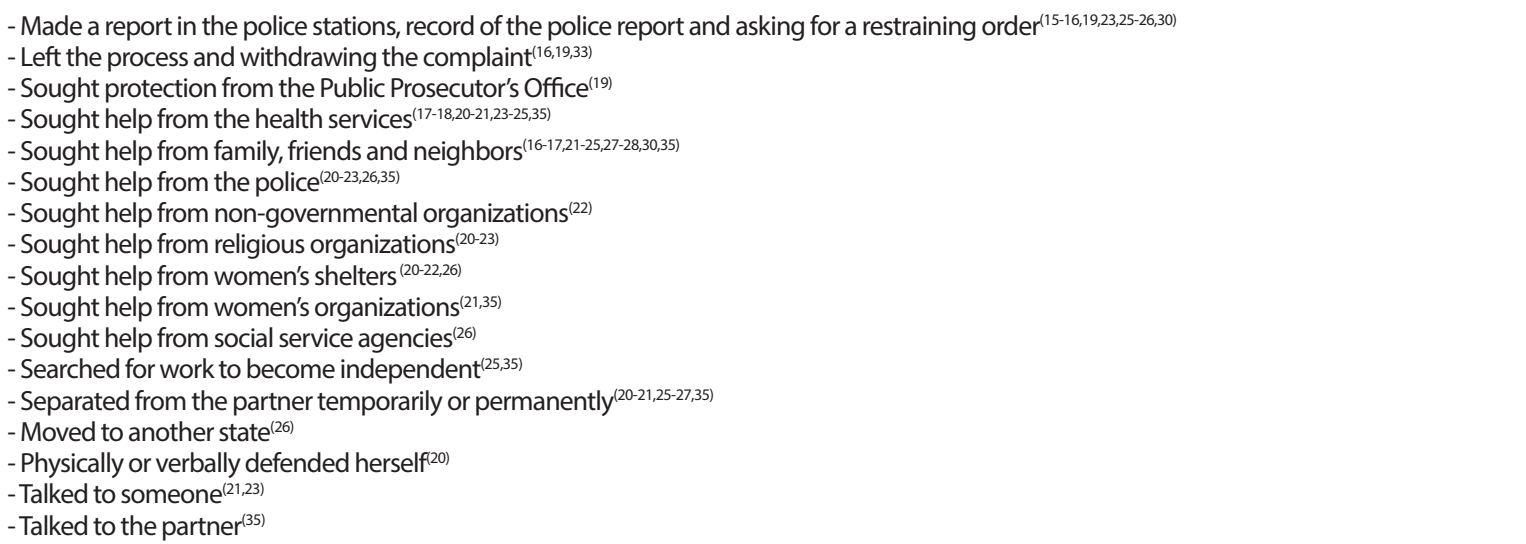 } \\
\hline
\end{tabular}


stations ${ }^{(16)}$. It is noted that women's knowledge of their rights has contributed to the increase in the number of complaints ${ }^{(15)}$.

The driving factors of the critical path related to the women's perceptions and behaviors were to assume that registration of police report at a women's police station will solve the situation of violence ${ }^{(16)}$, to understand that they are experiencing this situation $^{(16-17)}$ and that it has a public dimension ${ }^{(18)}$. Although they are experiencing aggression, some women only start the process of coping with violence ${ }^{(17)}$, such as to search for a service ${ }^{(16)}$ and authorities ${ }^{(18)}$, in the face of these understandings.

The driving factors related to the women's previous experiences were related to having children ${ }^{(19-22)}$. Often, these children also experience violence ${ }^{(19-20)}$, in addition to which there is a concern of women towards them ${ }^{(20-21)}$, especially because of their presence in their homes ${ }^{(22)}$. Many women remain in a situation of violence for several years, and only when their children also begin to experience it they are able to react and start the path ${ }^{(19)}$. In this sense, the study evidenced a significant association between the search for help by women and child abuse ${ }^{(20)}$. Other driving factors in the women's critical path were to be seriously wounded ${ }^{(21,23)}$, to have injuries, to be forced to have sex or to suffer violence during pregnancy ${ }^{(20)}$, as well as to be afraid or threatened by the offender ${ }^{(21,23-24)}$.

On the other hand, the studies showed several reasons why women remained in a situation of violence and did not start the path: fear of revenge from the offender ${ }^{(15,21-22,27)}$; threat ${ }^{(19,22)}$; financial dependence ${ }^{(19)}$; maintenance of the family nucleus ${ }^{(17,19)}$; preservation of their and the children's living conditions ${ }^{(17)}$; gender, family and cultural prejudices and stereotypes ${ }^{(17,19,22)}$; loving the partner ${ }^{(17)}$; belief that he will change ${ }^{(17) ;}$ for believing in the importance of the partner's participation in raising the children ${ }^{(17,22)}$; fear of starting a new life ${ }^{(17)}$; by minimizing/naturalizing violence ${ }^{(21-22,27)}$; embarrassment and shame $\mathrm{i}^{(17,21-22,26-27)}$; for believing that the partner will not change ${ }^{(22)}$, and to protect him and preserve the relationship ${ }^{(27)}$.

Other women, even though they started the path, they returned to the partner, and, consequently, to the situation of violence for being without money ${ }^{(26)}$; for being threatened, stalked or harassed by $\mathrm{him}^{(26)}$; for being encouraged by their families to resume the relationship $^{(24,26)}$; for feeling guilty ${ }^{(26)}$; for being alone ${ }^{(26)}$; for the good of the family/children ${ }^{(21,23)}$; to meet the request of the partner ${ }^{(23)}$; for loving him $^{(23,26)}$; and for understanding violence as something normal ${ }^{(21)}$.

The evidence about the driving factors related to the support of close people indicated that women in situations of violence rely especially on the support of family and friends ${ }^{(16-17,21-28)}$, among whom are mothers and mothers-in-law ${ }^{(17,26)}$, fathers, aunts, uncles, grandparents, siblings ${ }^{(26)} ;$ parents and siblings ${ }^{(23)}$, and the partner's own family members ${ }^{(23)}$.

\section{Response factors}

Regarding the response factors related to the availability and quality of services considered negative, the studies revealed a lack of protection and security/legal measures difficult to inspect $^{(15-17,19,22,24,26,29-32)}$. That is because many women, after going to the police station, returned home and were seriously injured ${ }^{(16)}$ and even killed by their partner ${ }^{(15-16)}$, since no police officer was able to protect them 24 hours a day ${ }^{(16,29)}$, which demonstrates the difficulty to inspect the compliance with legal measures ${ }^{(31)}$. Many, after registering the report, were sent away even though they had nowhere to $\mathrm{go}^{(16)}$. Other women did not have their request answered when they sought help from the police system, which $^{(24,26)}$ : denied the registration of the occurrence report ${ }^{(15)}$, told them to return another day to file the complaint because there were no people available to assist them ${ }^{(19)}$, discouraged the registration of the report $^{(22)}$ and sent the women to another precinct ${ }^{(24,32)}$.

The negative response factors were also related to the lack of police vehicles, the delay in the arrival of the police when the women requested help and the fact that the officers said they could not enter the house ${ }^{(16)}$. A study that reported six cases of feminicide showed that, in two of them, the victims had carried out several police reports both for injury and for death threats from the partner ${ }^{(30)}$, which revealed that many women repeatedly reported the offender, asking for protection, and were not heard ${ }^{(31)}$. Regarding the restraining order, despite the fact that many women obtained it formally, in practice the offenders were not held liable, and this measure was not complied with ${ }^{(15-16)}$.

The precariousness of the physical structure, of the institutions' human resources and of the social facilities was evidenced ${ }^{(15-19,22,26,29,31-34)}$. The precariousness applied to the police as well as to other institutions of the network ${ }^{(15)}$, being demonstrated by the lack of professionals in the different services ${ }^{(15,32)}$; the presence of professionals who did not wish to be in the position they were ${ }^{(19)}$; the lack of training/technical competence of professionals to work with violence ${ }^{(18,22,31-33)}$; the scarcity of resources ${ }^{(18,26) ;}$ the existence of reference services that only operated from Monday to Friday ${ }^{(16,31)}$; the inexistence of house-shelters ${ }^{(29)}$; and the lack of privacy ${ }^{(18,32,34)}$. Such aspects, among others, hindered the enforcement of the Maria da Penha Law in Brazil(15) and of legislations on domestic violence ${ }^{(18)}$. Thus, the public policies to combat violence were not put into practice by the services that provided assistance to women in situations of violence ${ }^{(15,17)}$. Resource scarcity is considered to be more extreme in rural communities, since in these environments women in situations of violence have less access to specialized services, services offered by NGOs or government organizations ${ }^{(18)}$.

Regarding the precariousness of human resources, studies revealed a work overload/lack of time ${ }^{(16,19,22,32-33)}$, especially in services of law enforcement ${ }^{(22)}$, police ${ }^{(16,33)}$ and health ${ }^{(32-33)}$. At the women's police station, there is work overload due to the responsibilities assigned to it, especially after the promulgation of the Maria da Penha Law ${ }^{(16)}$, and the professionals claimed that they did not have enough time to listen to the woman's life report ${ }^{(33)}$. In basic health units, there was a long waiting time for assistance, and many women still had to schedule the appointments, which could be discouraging ${ }^{(32)}$. In psychosocial care services, the time demanded for the women's treatment was considered long, which was a reason of their resistance to the psychotherapeutic treatment ${ }^{(33)}$. This work overload was a limiting factor for the networking practice ${ }^{(19)}$.

The absence of care protocols, of specific forms for case records and of notification, referral and evaluation of the measures adopted $^{(15-19,24,26,31-34)}$ were other negative aspects of availability and quality of services. A study carried out in different institutions that work with gender-based violence indicated the use of specific forms for reporting violence only in one Non-Governmental Organization (NGO) and in one psychology service linked to the police station $^{(19)}$. In some services, there were no forms for description 
of the performed referrals ${ }^{(15)}$, nor protocols for referrals or treatments ${ }^{(18,31)}$. In addition, the use of different languages in each service was identified ${ }^{(17)}$. In some of them, such as the reference center, reception and intersubjectivity were valued, whilst in the police station and in the courthouse, objectivity was valued ${ }^{(17)}$.

Also, the listening was identified as being based on the complaint ${ }^{(16,18,24,26,32-34)}$, especially in police stations and health services. In police stations, only the collection of information necessary to the beginning of the legal trajectory was regarded ${ }^{(16,33)}$. In health services, the assistance was focused on injuries ${ }^{(18)}$, visible marks ${ }^{(32)}$ and what was substantial regarding signs and symptoms $s^{(24)}$. In this perspective, women were often not questioned by the professionals about the source of the injuries ${ }^{(26)}$ or about the possibility of having experienced a situation of violence, even when it was suspected and when the women had generalized complaints and signs of aggression ${ }^{(34)}$.

The disruption of the network ${ }^{(15-19,24,26,29,31-33)}$ was demonstrated by the lack of integration and communication among professionals from various organs and sectors ${ }^{(15-17,19,31,33)}$, which led to an isolated practice in their area of operation ${ }^{(19)}$ and to the discontinuation of care $^{(31)}$. It was also demonstrated by the absence of interinstitutional flows $s^{(4,7,17)}$ and of follow-up of women by hospitals and basic health units, and in these cases the difficulty was related to the offender's reaction, when he lived with the woman ${ }^{(16)}$. Thus, disruption of the network was evidenced by the inexistence of reference and counter-reference, that is, when the services referred a woman in a situation of violence to another service and waited for the return of the provided assistance, which would not occur ${ }^{(31)}$. In face of these aspects, proposals such as the Maria da Penha Law, which demands resources from several sectors for its implementation ${ }^{(29)}$, have not been executed.

Disruption of the network was also demonstrated when services reduced their actions to referrals ${ }^{(24)}$, when these were limited to their area of action ${ }^{(33)}$, or when women were referred to neighboring municipalities due to the lack of a certain service where they lived ${ }^{(19)}$. The latter situation caused the women emotional distress, transport expenses and absence at work, which is considered another form of violence ${ }^{(19)}$. Many referrals were justified by the need for "specific" or "specialized" services, suggesting that violence was a responsibility only for the professionals who chose to deal with that type of problem ${ }^{(32)}$.

Such disruption was also noticed because of the precariousness of the judicial system, revealed by the length of legal proceedings $s^{(18,29,31,33)}$ and excessive bureaucracy ${ }^{(18)}$; also because of the lack of a specific court to address violence against women ${ }^{(31)}$ and the existence of adapted criminal courts, which are not always adequate for the full application of the measures provided for in the Maria da Penha Law $^{(15)}$. The disruption was pointed out by public defenders, who often did not know the woman they would represent at the court hearing and because of their turnover, considering that, during the same process, a woman could be assisted by several defenders ${ }^{(16)}$.

Additionally, the disruption can be identified due to the termination of legal proceedings on the first court hearing ${ }^{(16)}$ and due to hearings in which women were led to make decisions quickly ${ }^{(16)}$; due to the realization of deals and conciliatory procedures ${ }^{(18)}$, through which women were pressured by the authorities to reconsider the complaint and return home because they had nowhere to $\mathrm{go}^{(16)}$, having to forgive the offender ${ }^{(18)}$. Thus, women were left unprotected and had their rights violated, especially those related to the legal process ${ }^{(18)}$.

The absence of professionals from other areas to work together in the services ${ }^{(15,19)}$ and to create spaces of exchange among the members of the team ${ }^{(17,33)}$ is also another negative aspect of the network. The lack of assistance for the aggressor, which is an aspect contemplated in the Maria da Penha Law ${ }^{(15)}$, in addition to intervention programs for offenders focused on alcohol and drug abuse rather than on domestic violence ${ }^{(26)}$ can also be mentioned.

A study about the social network of women in situations of violence showed the existence of an informal network of people that could be reached ${ }^{(17)}$, instead of a network constituted of services. It also pointed out that the professionals did not make an effort to get in touch with the elements of the women's social network, demonstrating the lack of interaction with the actors close to the women both spatially and affectively ${ }^{(17)}$.

The scientific evidence of the response factors related to the availability and quality of the services considered positive indicated that the police authorities monitored the women in safety for removal of their belongings from the house ${ }^{(15-16)}$, took them to shelters or relatives' homes ${ }^{(16)}$, as well as realized the removal of the partner from the house ${ }^{(15)}$. These functions were implemented in Brazil after the Maria da Penha Law ${ }^{(15-16)}$.

The aid of support groups ${ }^{(29)}$ and self-help groups $s^{(16,29,32)}$, such as Alcoholics Anonymous, Narcotics Anonymous and Demanding Love ${ }^{(16,32)}$ were pointed out. These groups have collaborated in assisting women in situations of violence ${ }^{(5)}$ and in facing this problem ${ }^{(16,32)}$.

Regarding the referral of women to other services and institutions ${ }^{(16,18,29,32-33)}$, a study pointed out that, when treated in hospitals, women were referred to other services, depending on the type of aggression suffered ${ }^{(16)}$. Other examples were: referral of a woman from a health unit to the Legal Medical Department, to a social worker and a shelter house ${ }^{(16)}$; from a Women's Police Station (WPS) to an NGO, to a study group of support for victims of violence, and to legal assistance and the courthouse ${ }^{(29)}$; from a WPS to a psychologist; and in cases of sexual violence, to a reference hospital ${ }^{(32)}$. In this sense, the WPSs were identified as active participants in the referral network as recipients and senders ${ }^{(33)}$. From an NGO that fights violence against women, the woman could be referred to different health units, depending on the type of violence, both domestic and sexual violence ${ }^{(29)}$. Community organizations, even if not specifically targeted at family violence, also conducted women to institutions, when available ${ }^{(18)}$.

The search for the strengthening of the women's self-esteem, their economic independence and life planning was evidenced, so that when they felt safe they could file the police report ${ }^{(19)}$. There was appreciation of intersubjective relationships and promotion of growth and changes in women, seeking the reorganization ${ }^{(17)}$ and re-signification of their lives after the experienced trauma ${ }^{(29)}$. Therefore, the professionals aimed at counseling women for them to seek safe, productive and independent lives ${ }^{(26)}$, promoting their emancipation and empowerment ${ }^{(33)}$.

The assistance provided by the professionals of the services $^{(16-19,29,32-33)}$ and the counseling of women ${ }^{(16-17,19)}$ in hospitals were also revealed. The given counseling regarded the search of the public prosecutor's office by the woman ${ }^{(16)}$, and the ones given in NGOs were related to the completion of the police report, since 
in serious cases its implementation could aggravate the situation of violence ${ }^{(16)}$. When given by church members, the counseling was important for a satisfactory outcome of the situation ${ }^{(17)}$.

Empathy, sensitivity and acceptance were also aspects of the provided assistance, and in the studies evaluated, they were demonstrated by health professionals ${ }^{(16,18)}$. A study highlighted that when women were welcomed by the network services, there was success in coping with violence ${ }^{(17)}$. Other positive factors were the discussion of the case ${ }^{(19,29)}$ by a multidisciplinary team in an $\mathrm{NGO}^{(19)}$ and in a interinstitutional way between an organization dealing with violence against women, health facilities, health departments, education and social assistance ${ }^{(29)}$.

Other aspects indicated were the women's complete physical, psychological and legal assistance developed by an $\mathrm{NGO}^{(29)}$; the knowledge of professionals about the mission of their institution or organization ${ }^{(29)}$; and the standardized routine organized in flows in women's police stations ${ }^{(32-33)}$.

Scientific evidence of response factors related to social representations of service and community servers considered negative pointed to blame, discrimination of women, patriarchal conceptions and moral judgment ${ }^{(15,17-19,24,26,31-33)}$. These factors are evidenced when the professionals blame the women for the violence experienced $^{(15)}$ and make moral judgments ${ }^{(33)}$, either by affirming that some women suppose that the men do not like them anymore if they do not use violence ${ }^{(19)}$ or by trying to justify aggressions, offenses and humiliations inflicted on women because of their inappropriate or provocative behavior ${ }^{(17)}$ or because of the use of substances ${ }^{(32)}$. This also occurred when the parents believed that the woman was wrong, making them, sometimes, return to the offender ${ }^{(24)}$ and consequently to the situation of violence.

In the services, judges trivialized the Maria da Penha Law instead of enforcing it ${ }^{(15)}$; doctors stated that it was not possible to believe in all of the stories of women who said they were living in situations of sexual violence because they would make false accusations of abortion; when professionals in the police station discriminated against women ${ }^{(32)}$, made statements based on gender stereotypes and myths about family violence ${ }^{(18)}$ and when they disqualified, trivialized and laughed at the pain of women when they filed a complaint against their husbands for rape ${ }^{(32)}$. This led many to not believe that the police station could help them ${ }^{(31)}$. When the situation of violence was ignored or minimized in seeking help, women felt guilty and silenced ${ }^{(26)}$.

Other representations of professionals and the community are related to: the understanding of violence as a disease to be treated ${ }^{(15)}$; the consideration of the Maria da Penha Law as unconstitutional by some judges, who argued that it contravened equal rights between men and women ${ }^{(15)}$; the understanding of the restraining order as a role of symbolic value, which could be respected or not by the offender ${ }^{(15)}$; the perception that violence posed no real danger to women ${ }^{(18)}$; the understanding that the other services were competitors and not partners in interdisciplinary and interinstitutional work ${ }^{(19)}$; the devaluation of the women's police station by the police ${ }^{(33)}$; and the knowledge of some professionals only about their own sector of activity ${ }^{(19)}$. Regarding this last representation, the professionals were also unaware of the way a woman in a situation of violence should go in search for help and which resources were more efficient or which ways were more agile and with less suffering for the women when they sought help ${ }^{(19)}$.

These representations were in addition to the conceptions that violence against women was a matter of private domain ${ }^{(29,33-34)}$, and therefore difficult to be noticed and to receive intervention by the public power ${ }^{(29)}$ and the health services ${ }^{(34)}$, for example. Such representations can be explained by the fact that domestic crimes are socially and historically considered less important than those of the public sphere ${ }^{(33)}$.

Scientific evidence of the positive response factors related to social representations of service and community servers indicated the understanding of the Maria da Penha Law as an innovative legal device ${ }^{(15,29)}$ created in order to punish more severely the woman's offender ${ }^{(15)}$. Among the aspects of the Law, which are considered advancements, is the requirement to create shelter homes and to care for the offender ${ }^{(29)}$. The evidence also pointed out the understanding of the importance of networking ${ }^{(17,33)}$, according to which professionals recognized the need for integration between the different services ${ }^{(33)}$ in view of the difficulties of isolated work ${ }^{(17)}$; and awareness of professionals regarding violence $\mathrm{e}^{(29,32,34)}$, among them doctors and nurses ${ }^{(34)}$.

Regarding the scientific evidence of the response factors in relation to the negative results, negative responses from the law enforcement, police and judicial sectors were indicated ${ }^{(18,26)}$. In the 10 countries-scenario of one of the studies, these were the sectors that offered the worst responses to women who sought help ${ }^{(18)}$. Another study pointed out that when women called the police, it did nothing to improve the situation of violence ${ }^{(26)}$.

Regarding the health sector response, it was limited to the treatment of injuries ${ }^{(18,26,32)}$, for which the women received assistance and then returned to the offender who inflicted the injuries ${ }^{(26)}$. This response is due to the supposed specificity of the hospital service: treatment of serious and/or life-threatening injuries ${ }^{(32)}$. Therefore, the women considered the institutions of the health sector to be those that could treat their injuries or illnesses, but in which they could not discuss their experiences of violence ${ }^{(18)}$.

Regarding the educational sector, there were no responses from it, since professionals considered gender and family violence issues that deviated from the domain of educational policy and curriculum ${ }^{(18)}$. A study about the help-seeking behaviors of women who have already experienced in their lives physical and/or sexual violence by an intimate partner revealed that more than $40 \%$ of them were not helped by anyone ${ }^{(21)}$.

Scientific evidence of response factors related to the positive results indicated the reduction of cases of physical injury after the Maria da Penha Law ${ }^{(15)}$, because when the woman registered the threat complaint and requested the restraining order, rarely there was injury ${ }^{(15)}$. The evidence also indicated the cessation of violence from the partner after the registration of a police report or imprisonment ${ }^{(16,26)}$ in some cases, however it was temporary ${ }^{(26)}$.

The support of women's organizations dedicated to violence against women $^{(18)}$ is emphasized, especially from those that provided services related to women's health and legal rights, being pioneers of the promotion of public policies to prevent, tackle and eradicate the problem ${ }^{(18)}$. There are also positive responses from religious institutions ${ }^{(17-18)}$, which were a point of reference, even if they did not offer specific services for women ${ }^{(8)}$; and from the police ${ }^{(21-22)}$, which depended on the type and severity of violence experienced by women ${ }^{(22)}$. 


\section{Decisions made and actions taken}

Scientific evidence of the decisions made and actions taken by the women pointed out the performance of complaints in police stations, registration of the police report and request for restraining order ${ }^{(15-16,19,23,25-26,30)}$. Regarding these aspects, studies pointed out that some professionals assume that there are women who take such actions without experiencing a situation of violence, but for the partner to move away from the house because of the end of the relationship or when there is no more interest or love for the partner ${ }^{(15-16)}$. On the other hand, a study revealed that the women who most called the police reported that this type of search for help was extremely dangerous ${ }^{(26)}$.

Many women quit following the proceedings and withdrew the complaint ${ }^{(16,19,33)}$ and, thus, few ended with the penalty being applied to the offender ${ }^{(19)}$. In cases of withdrawal, the professionals blamed the women, claiming that they opened procedures and demanded protection, burdening services and hampering the proper functioning of the system ${ }^{(19)}$. Thus, the complaint of women loses credibility from the perspective of professionals $^{(33)}$.

Another decision made and action taken was the search for protection from the Public Prosecutor's Office ${ }^{(19)}$, especially in extreme situations where there is severe violence and risk of death, in which women do not wait for the court hearing ${ }^{(19)}$ nor seek help in services ${ }^{(17-18,20-21,23-25,35)}$, such as hospitals and health centers ${ }^{(20,23-24)}$. As for hospitals, the women looked for them when they were seriously injured, presenting bleeding. Health centers, however, were sought when traumas were considered mild by women ${ }^{(24)}$.

The women also sought help from family, friends and neighbors $^{(16-17,21-25,27-28,30,35)}$; from the police ${ }^{(20-23,26,35)}$; from non-governmental organizations ${ }^{(22)}$; from religious organizations ${ }^{(20-23)}$; from women's shelters ${ }^{(20-22,26)}$; from women's organizations ${ }^{(21,35)}$; and from social service agencies ${ }^{(26)}$.

Women sought work to become financially independent ${ }^{(25,35)}$; separated from the partner temporarily or permanently ${ }^{(20-21,25-27,35)}$; moved to another state ${ }^{(26)}$; defended themselves physically or verbally ${ }^{(20)}$; talked to someone ${ }^{(21,23)}$ or to the partner, in order for him to change his behavior ${ }^{(35)}$.

\section{Study limitations}

The limitations are related to the complexity of combining studies with different methodological approaches, to the restriction of searching in English, Portuguese and Spanish, and to not consulting gray literatures such as theses and dissertations.

\section{Contributions to Nursing, Health and Public Policies}

With regard to the driving factors, it is recommended to increase women's access to information about their rights and the places/services where they can seek assistance/help, which could promote the beginning of the path. It is necessary to make women aware that the solution of situations of violence goes beyond the women's police station, and that there is a set of services and people who can assist and support them. With regard to response factors, aiming at multidisciplinary and intersectoral work based on reception, empathy and absence of gender stereotypes and moral judgment, it is recommended to use care protocols and increase and qualify human resources in services.

\section{CONCLUSION}

Among the driving factors of the critical path, serious violence, fear or threats stood out in the synthesis of this review. Lack of protection, poor infrastructure, insufficient human resources of institutions, disruption of the network and victim blaming are negative factors for response. The positive response factor focuses on the referral of women and the reorganization of life. Regarding the decisions made and actions taken, the highlights were complaints, access to health and police service, search for help from family, friends and neighbors, and separation. The critical path diagram's elements are articulated with each other and may promote, inhibit or delay the beginning of the path by the woman, affecting the outcome of situations of violence.

When considering the critical appraisal of the articles through evidence classification from the primary studies, according to the type of research question, most were of meaning and level 2, which indicates the gap of meta-synthesis. On the other hand, prognostic/ etiology-type articles, all of level 4, indicate the need for systematic reviews and primary studies of the cohort or case-control type. No intervention-type articles were retrieved, which indicates another gap.

\section{FUNDING}

The present work was performed with the support of the Coordination for the Improvement of Higher Education Personnel - Brazil (CAPES) - Funding Code 001.

\section{REFERENCES}

1. World Health Organization (WHO). Responding to intimate partner violence and sexual violence against women: WHO clinical and policy guidelines [Internet]. Geneva: WHO; 2013 [cited 2018 Jan 10]. Available from: http://apps.who.int/iris/ bitstream/10665/85240/1/9789241548595_eng.pdf

2. Organização de las Naciones Unidas (ONU). Estudio a fondo sobre todas las formas de violencia contra la mujer. [Internet]. Ginebra: ONU; 2006 [cited 2018 Jan 11]. Available from: https://www.acnur.org/fileadmin/Documentos/BDL/2016/10742.pdf

3. Waiselfisz JJ. Mapa da Violência 2015: Homicídios de mulheres no Brasil [Internet]. Brasília: Organização Pan-Americana de Saúde, Organização Mundial de Saúde; 2015 [cited 2018 Jan 10]. Available from: http://www.mapadaviolencia.org.br/pdf2015/ MapaViolencia_2015_mulheres.pdf 
4. Senado Federal (BR). Instituto de Pesquisa DataSenado. Observatório da Mulher contra a Violência. Secretaria da Transparência. Violência doméstica e familiar contra a mulher: Pesquisa DataSenado [Internet]. Brasília: Senado Federal; 2017. [cited 2017 Dec 03]. Available from: https://www12.senado.leg.br/institucional/datasenado/arquivos/aumenta-numero-de-mulheres-que-declaram-ter-sofrido-violencia

5. Netto LA, Moura MAV, Queiroz ABA, Tyrrell MAR, Bravo MMP. Violence against women and its consequences. Acta Paul Enferm. 2014;27(5):458-64. doi: 10.1590/1982-0194201400075

6. Devries KM, Mak JY, Bacchus LJ, Child JC, Falder G, Petzold M, et al. Intimate partner violence and incident depressive symptoms and suicide attempts: a systematic review of longitudinal studies. PLoS Med 2013;10(5):e1001439. doi: 10.1371/journal.pmed.1001439

7. Martín-Baena D, Montero-Piñar I, Escribà-Agüir V, Vives-Cases C. Violence against young women attending primary care services in Spain: prevalence and health consequences. Fam Pract. 2015;32(4):381-6. doi: 10.1093/fampra/cmv017

8. Zancan N, Wassermann V, Lima GQ. A violência doméstica a partir do discurso de mulheres agredidas. Pensando Fam [Internet]. 2013[cited 2018 Jan 30];17(1):63-76. Available from: http://pepsic.bvsalud.org/scielo.php?script=sci_arttext\&pid=S1679-494X2013000100007

9. Sagot M. Ruta critica de las mujeres afectadas por la violência intrafamiliar en América Latina: estudios de caso de diez países. Washington: Organización Panamericana de la Salud; 2000. doi: 10.13140/2.1.4019.8726

10. United Nations General Assembly (UNGA). Transforming our world: the 2030 Agenda for Sustainable Development [Internet]. UNGA; 2015 [cited 2018 Jan 30]. Available from: https://sustainabledevelopment.un.org/content/documents/21252030\%20Agenda\%20for\%20 Sustainable\%20Development\%20web.pdf

11. Whittemore R, Knafl K. The integrative review: updated methodology. J Adv Nurs. 2005;52(5):546-53. doi: 10.1111/j.1365-2648.2005.03621.x

12. The Joanna Briggs Institute (JBI). Joanna Briggs Institute Reviewers' Manual: 2014 edition. [Internet] Adelaiade: JBI; 2014 . [cited 2018 June 10]. Available from: https://nursing.Isuhsc.edu/JBI/docs/ReviewersManuals/Economic.pdf

13. Fineout-Overholt E, Stillwell SB. Asking compelling, clinical questions. In: Melnyk BM, Fineout-Overholt E, editors. Evidence-based practice in nursing \& healthcare: a guide to best practice. Philadelphia: Wolters Kluwer Health/Lippincott Williams \& Wilkins; 2011. p. 25-39

14. Moher D, Liberati A, Tetzlaff J, Altman DG; PRISMA Group. Preferred reporting items for ; systematic reviews and meta-analyses: the PRISMA statement. PloS Med. 2009;6(7):e1000097. doi: 10.1371/journal.pmed.1000097

15. Meneghel SN, Mueller B, Collaziol ME, Quadros MM. Repercussões da Lei Maria da Penha no enfrentamento da violência de gênero. Ciênc Saúde Colet. 2013;18(3):691-700. doi: 10.1590/S1413-81232013000300015

16. Meneghel SN, Bairros F, Mueller B, Monteiro D, Oliveira LP, Collaziol ME. Rotas críticas de mulheres em situação de violência: depoimentos de mulheres e operadores em Porto Alegre, Rio Grande do Sul, Brasil. Cad Saúde Pública. 2011;27(4):743-52. doi: 10.1590/ S0102-311X2011000400013

17. Dutra ML, Prates PL, Nakamura E, Villela WV. A configuração da rede social de mulheres em situação de violência doméstica. Ciênc Saúde Colet. 2013;18(5):1293-1304. doi: 10.1590/S1413-81232013000500014

18. Sagot M. The Critical Path of women affected by family violence in Latin America. Violence Against Women. 2005;11(10):1292-318. doi: $10.1177 / 1077801205280189$

19. Presser AD, Meneghel SN, Hennington ÉA. Mulheres enfrentando as violências: a voz dos operadores sociais. Saúde Soc. 2008;17(3):126-37. doi: 10.1590/S0104-12902008000300013

20. Ellsberg MC, Winkvist A, Peña R, Stenlund H. Women's strategic responses to violence in Nicaragua. J Epidemiol Community Health. 2001;55:547-55. doi: 10.1136/jech.55.8.547

21. Fanslow JL, Robinson EM. Help-Seeking behaviors and reasons for help seeking reported by a representative sample of women victims of intimate partner violence in New Zealand. J Interpers Violence. 2010;25(5):929-51. doi: 10.1177/0886260509336963

22. Frías SM. Strategies and Help-Seeking behavior among mexican women experiencing partner violence. Violence Against Women. 2013;19(1):24-49. doi: 10.1177/1077801212475334

23. Silva RA, Araújo TVB, Valongueiro S, Ludermir AB. Facing violence by intimate partner: the experience of women in an urban area of Northeastern Brazil. Rev Saúde Pública. 2012;46(6):1-8. doi: 10.1590/S0034-89102013005000007

24. Santi LN, Nakano AMS, Lettiere A. Percepção de mulheres em situação de violência sobre o suporte e apoio recebido em seu contexto social. Texto Contexto Enferm. 2010;19(3):417-24. doi: 10.1590/S0104-07072010000300002

25. Montero I, Martín-Baena D, Escribà-Agüir V, Vives-Cases C, Ruiz-Pérez I. Factors associated with the cessation of intimate partner violence in women attending Primary Care in Spain. J Fam Violence. 2015;30(4):453-60. doi: 10.1007/s10896-015-9684-z

26. Moe AM. Silenced voices and structured survival: battered women's help seeking. Violence Against Women. 2007;13(7):676-99. doi: $10.1177 / 1077801207302041$

27. Fugate M, Landis L, Riordan K, Naureckas S, Engel B. Barriers to domestic violence help seeking: implications for intervention. Violence Against Women. 2005;11(3):290-310. doi: 10.1177/1077801204271959

28. Barrett BJ, St. Pierre M. Variations in women's help seeking in response to intimate partner violence: findings from a Canadian populationbased study. Violence Against Women. 2011;17(1):47-70. doi: 10.1177/1077801210394273

29. Santos MA, Vieira EM. Recursos sociais para apoio às mulheres em situação de violência em Ribeirão Preto, SP, na perspectiva de informantes-chave. Interface (Botucatu). 2011;15(36):93-108. doi: 10.1590/S1414-32832011000100008 
30. Meneghel SN, Ceccon RF, Hesler LZ, Margarites AF, Silva SR, Vasconcelos VD. Femicide: narratives of gender crimes. Interface (Botucatu). 2013;17(46):1-17. doi: 10.1590/S1414-32832013000300003

31. Silva EB, Padoin SMM, Vianna LAC. Women in situations of violence: limits of assistance. Ciênc Saúde Colet. 2015;20(1):249-58. doi: $10.1590 / 1413-81232014201.21202013$

32. Villela WV, Vianna LAC, Lima LFP, Sala DCP, Vieira TF, Vieira ML, et al. Ambiguidades e contradições no atendimento de mulheres que sofrem violência. Saúde Soc. 2011;20(1):113-23. doi: 10.1590/S0104-12902011000100014

33. Kiss LB, Schraiber LB, d'Oliveira AFPL. Possibilidades de uma rede intersetorial de atendimento a mulheres em situação de violência. Interface Comun Saúde Educ. 2007;11(23):485-501. doi: 10.1590/S1414-32832007000300007

34. Vieira EM, Ford NJ, De Ferrante FG, Almeida AM, Daltoso D, Santos MA. The response to gender violence among Brazilian health care professionals. Ciênc Saúde Colet. 2013;18(3):681-90. doi: 10.1590/S1413-81232013000300014

35. Montero I, Ruiz-Pérez I, Escribà-Agüir V, Vives-Cases C, Plazaola-Castaño J, Talavera M, et al. Strategic responses to intimate partner violence against women in Spain: a national study in Primary Care. J Epidemiol Community Health. 2012;66(4):352-8. doi: 10.1136/jech.2009.105759 